\title{
Droplet size and spray volume effects on honey mesquite mortality with clopyralid
}

\author{
S.G. WHISENANT, L.F. BOUSE, R.A. CRANE, AND R.W. BOVEY
}

\begin{abstract}
Whisenant and Crane are associate professor and research associate, Department of Rangeland Ecology and Management, Texas A\&M University, College Station 77843-2126; Bouse is research leader, Aerial Application Research Unit, Southern Crops Research Lab., ARS-USDA, Dept. of Agricultural Engineering, Texas A\&M Univ., College Station 77843; and Bovey is research agronomist, ARS-USDA, Dept. of Rangeland Ecology and Management, Texas A\&M University, College Station 77843-2126.
\end{abstract}

\section{Abstract}

The effects of droplet size and spray volume (spray-mixture application rate) on honey mesquite (Prosopis glandulosa Torr.) mortality were evaluated using 0.55 to $0.58 \mathrm{~kg}$ ae (acid equivalent) $\mathrm{ha}^{-1}$ clopyralid (3,6 dichloro-2-pyridinecarboxylic acid). A factorial combination of 3 spray volumes $\left(19,37\right.$, and 75 liters ha $\left.\mathrm{ha}^{-1}\right)$ and droplet sizes of $325 \pm 25,475 \pm 25$, and $625 \pm 25 \mu \mathrm{m}$ nominal $D_{v .5}$ (volume median diameter) were replicated 3 times at both Andrews and Big Lake, Tex., during June 1989. The experiment was repeated in 1990 at Big Lake and Campbellton, Tex., without the 75 liters $\mathrm{ha}^{-1}$ spray volume. Honey mesquite mortality and canopy reduction 16 months after application were significantly less on the $625 \mu \mathrm{m}$ droplet treatments in 2 of 4 experiments, when compared to plots treated with smaller droplet sizes. Mortality increased with larger spray volumes, particularly with $625 \mu \mathrm{m}$ droplets. Relative mortality data from the 4 experiments clearly demonstrated that larger droplet sizes require larger spray volumes for greatest efficacy.

Key Words: herbicides, droplet size, spray-mixture application rate, spray volume, Prosopis glandulosa

Aerial application of herbicides requires management decisions that involve compromises among efficacy, safety, and economics. The application of greater volumes of spray solution may improve herbicide efficacy but also increases treatment costs. Smaller droplet sizes increase drift potential, but may improve herbicide efficacy. Aerial applicators seek to improve efficacy while balancing the risks associated with smaller droplets and the greater costs associated with increased spray volumes. Despite a general appreciation for these variables, the relationships between efficacy, droplet size, and spray volume have not been demonstrated during actual rangeland applications.

Phytotoxicity is usually increased when leaves absorb more herbicide. Herbicide absorption is increased with greater herbicide concentrations in the spray solution and more contact area between the leaf surface and the herbicide solution (McKinlay et al. 1972, 1974; Cranmer and Linscott 1991). The contact area between the spray solution and leaf surface is increased by using surfactants to reduce droplet surface-tension, increasing the amount of spray solution applied (spray volume), and decreasing droplet size

\footnotetext{
The authors wish to thank Dow Elanco; The 74 Ranch; The University of Texas System-University Lands; Nalco Chemical Co.: the Brush Control and Range Improvement Associaton; and Rhom and Haas Co. for their support of this research. We also appreciate the assistance of J.B. Grumbles, R.A. Stermer, E. Franz, J.H. Price, C.B. Harris, R.D. Mitchell, P.C. Jank, J.Smith, S.C. Ransom, C. Hoffman, K. Walz, D. McCommas, M. Gurrola, L. Cox, V.S. House, T, Blackwell, H. Tom, R. Johnson, and J.B. Carlton. P.W. Jacoby, T.G. Welch, and H.T. Wiedemann provided helpful reviews of an earlier manuscript version.

Published with approval of Director, Texas Agricultural Experiment Station as TA-30639.

Accepted 19 Sept. 1992.
}

(which increases droplet density). Surfactants are routinely used and have no disadvantages, but the selection of droplet size and spray volume inevitably requires tradeoffs between efficacy, expense, and risk. For a given herbicide application rate, herbicide concentration (in the spray solution) is increased as spray volume decreases. Thus, spray volume selection requires a balance between herbicide concentration and the increased distribution of herbicide on the leaf surface associated with larger spray volumes.

Although greater spray volumes should improve herbicide distribution on the leaf surface, several scientists have reported reduced phytotoxicity with increasing spray volumes (McKinlay et al. 1972, 1974; Buhler and Burnside 1983, 1984, 1987; Cranmer and Linscott 1991). Those reductions in phytotoxicity were attributed to reduced herbicide concentrations in the spray solution when using greater than normal spray volumes. For example, formulated glyphosate [ $N$-(phosphonomethyl)glycine] absorption was greater when a single concentrated droplet was applied to velvetleaf (Abutilon theophrasti Medik.) compared to when a greater number of more dilute drops was applied (Cranmer and Linscott 1991). They found that at small herbicide concentrations, the steepness of the herbicide concentration gradient across the cuticle and plasmalemma was reduced and concluded that absorption rate was increased when the spray solution contained high concentrations of glyphosate.

In greenhouse experiments using formulated herbicides, fluazifopbutyl $\{(\mathrm{R})$-butyl, 2-[4-[[5-(trifluoromethyl)-2-pyridinyl] $0 x y]$ phenoxy]proponoate\}, haloxyfop-methyl [methyl $2-\{4-[[3-c h l o r o-5-(t r i-$ fluromethyl)-2-pyridinyl]oxy]phenoxy]propanoate $\}$, and sethoxydim \{2-[1-(ethoxyimino)butyl]-5-[2-(ethylthio)propyl]-3-hydroxy-2-cyclohexene-1-one\} toxicity to forage sorghum (Sorghum sp.) and yellow foxtail (Setaria glauca (L.) Beauv.) increased as spray volume decreased from 570 to 24 liters ha ${ }^{-1}$. Field results corroborated greenhouse data and indicated a general increase in phytotoxicity with all herbicides as spray volume decreased from 570 to 24 liters ha ${ }^{-1}$. This part of the study did not consider associated changes in droplet size. They stated that the smaller orifice nozzles used to produce the smaller volumes probably produced smaller droplets, which resulted in greater phytotoxicity (Buhler and Burnside 1984).

In aerial applications, spray volumes are changed by altering nozzle orifice size, pressure, number of nozzles, and aircraft speed. These factors affect droplet size, yet previous field studies have not evaluated the relationship between spray volume and droplet size. An understanding of these relationships and their influence on honey mesquite (Prosopis glandulosa Torr.) mortality will facilitate the selection of safe and effective herbicidal management practices.

Our objectives were to evaluate the effects of and the relation- 
Table 1. Description of site and soil temperature where experiments were applied to evaluate spray volume and droplet size effects on honey mesquite.

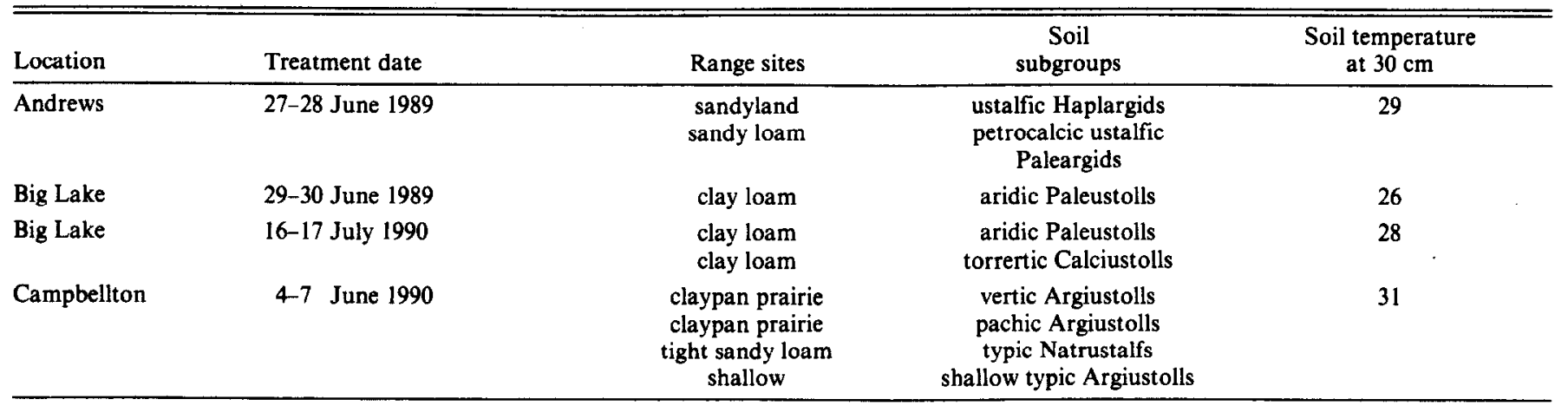

ships between spray volume and droplet size on honey mesquite mortality with clopyralid (3,6 dichloro-2-pyridinecarboxylic acid).

\section{Materials and Methods}

The monoethanolamine salt of clopyralid was applied at 4 locations in west and south Texas in 1989 and 1990. A randomized, complete block design with a factorial combination of treatments, including spray volumes of 19,37 , and 75 liters ha $\mathrm{ha}^{-1}$ and spray droplet sizes of $325 \pm 25,475 \pm 25$, and $625 \pm 25 \mu \mathrm{m}$ nominal $\mathrm{D}_{\mathrm{v} .5}$ (volume median diameter) were replicated 3 times. Experiments were applied at Andrews (Andrews County) and Big Lake (Reagan County) in west Texas during 1989. With the exception of treatments containing the 75 liters $\mathrm{ha}^{-1}$ spray volumes, the experiment was repeated in 1990 at Big Lake and Campbellton (Atascosa County) Tex. Application dates, sites, and soil temperatures are listed in Table 1 . The 1989 treatments contained $0.58 \mathrm{~kg}$ ae (acid equivalent) clopyralid $\mathrm{ha}^{-1}$ and the 1990 treatments contained 0.55 $\mathrm{kg}$ ae clopyralid ha ${ }^{-1}$. The clopyralid was applied in a diesel:water emulsion [1:5(v:v)] containing $3 \mathrm{ml}$ of a $1 \%$ polyvinyl polymer liter $^{-1}$ spray solution as a drift control agent.

Preliminary studies were conducted to determine configurations which produced the desired spray volume and droplet size combinations. The different spray volume rates were obtained with conventional hydraulic disc-core nozzles by varying nozzle orifice size, number of nozzles on the spray boom, spray pressure, nozzle orientation relative to horizontal and back, and with presence or absence of a core in the nozzle (Table 2). Droplet statistics were estimated with a droplet size spectrometer system (Particle Measurement Systems Company, Boulder, Colo.) using equipment and procedures described by Bouse et al. (1990) under simulated aerial application conditions for airspeed and nozzle parameters. Droplet spectrums from nozzles operated in the airstream from a highspeed blower were measured for airspeed and nozzle parameters included in the field studies.

Applications were made with a Cessna T188C Ag-Husky agricultural aircraft equipped with a 9.8-m long, straight spray boom. The aircraft was flown at a height of 4 to $5 \mathrm{~m}$ above the honey mesquite canopy at an airspeed of $192 \mathrm{~km} \mathrm{ha}^{-1}$ using a $13.7-\mathrm{m}$ swath spacing. The 1989 plots consisted of 5 adjacent $402-\mathrm{m}$ long swaths. The 1990 plots at Big Lake were 7 swaths wide and 402-m long, while the Campbellton plots had six, 518-m long swaths.

A portable weather station was placed within 1 of the untreated plots at each study site to record temperature, relative humidity, wind speed and angle of the wind relative to flight direction at 5 -minute intervals during treatment application. Measurements were made at a height of $2.5 \mathrm{~m}$ above ground level for all tests except Big Lake, 1990; where the measurements were taken at $5 \mathrm{~m}$. The distance of the treated plots from the weather measurement system ranged from about $40 \mathrm{~m}$ to $2 \mathrm{~km}$. As a result, the weather data were not necessarily representative of conditions at a given plot at the time of application. This is particularly true for the wind measurements, which changed rapidly with time and distance. The aircraft flaggers exercised judgment as to when the wind was excessive in speed or crosswind angle and advised the pilot by radio to make or delay the application of each spray swath applied.

Treatments were evaluated following the second post-treatment growing season (Oct. 1990 and Scpt. 1991). Canopy reduction and plant mortality were estimated on at least 150 trees in each plot and

Table 2. Nozzles, spray volume application rates, and droplet size statistics for sprays used to apply experiments. Applications were made with a Cessna T-188C Ag-Husky equipped with a 9.8-m spray boom. All sprays were a diesel:water emulsion [1:5 (v:v)] containing $3 \mathrm{ml}$ of a $1 \%$ polyvinyl polymer liters $^{-1}$ spray solution as a drift control agent.

\begin{tabular}{|c|c|c|c|c|c|c|c|c|}
\hline $\begin{array}{l}\text { Spray volume } \\
\text { application rate }\end{array}$ & $\begin{array}{c}\text { Nozzle } \\
\text { type }\end{array}$ & Pressure & $\begin{array}{c}\text { Nozzle } \\
\text { orientation }\end{array}$ & $D_{\mathrm{v} .5}$ & $\begin{array}{l}\text { Volume }^{3} \\
<204 \mu \mathrm{m}\end{array}$ & $\begin{array}{l}\text { Volume }^{4} \\
>415 \mu \mathrm{m}\end{array}$ & $\begin{array}{l}\text { Relative } \\
\text { span }^{5}\end{array}$ & $\begin{array}{l}\text { Number } \\
\text { of nozzles }\end{array}$ \\
\hline (liters ha ${ }^{-1}$ ) & & $(\mathrm{kPa})$ & (degrees) & $(\mu \mathrm{m})$ & (\%) & $(\%)$ & & \\
\hline 18.7 & D4-46 & 207 & 32 & 327 & 6.81 & 21.2 & 0.73 & 52 \\
\hline 18.7 & D4 & 138 & 0 & 481 & 1.00 & 65.9 & 1.19 & 62 \\
\hline 18.7 & D4 & 359 & 0 & 626 & 0.46 & 81.5 & 0.96 & 38 \\
\hline 37.4 & D6-46 & 138 & 30 & 327 & 8.04 & 25.7 & 1.00 & 61 \\
\hline 37.4 & D6 & 207 & 10 & 451 & 1.71 & 58.9 & 1.16 & 43 \\
\hline 37.4 & D5 & 379 & 0 & 628 & 0.56 & 81.1 & 1.27 & 47 \\
\hline 74.8 & D10-46 & 207 & 0 & 323 & 6.53 & 19.7 & 0.83 & 49 \\
\hline 74.8 & D7 & 207 & 0 & 487 & 1.28 & 67.2 & 1.01 & 64 \\
\hline 74.8 & D7 & 379 & 0 & 623 & 0.93 & 78.8 & 1.03 & 50 \\
\hline
\end{tabular}

1Nozzle designation refers to disc-core combination

${ }_{2}^{2}$ Relative to airstream direction (horizontal and back). Nozzles were tested at $192 \mathrm{~km} \mathrm{~h}^{\text {"1 }}$ simulated airspeed (created by highspeed blower).

3Percentage of the spray volume in droplets smaller than $204 \mu \mathrm{m}$.

4Percentage of the spray volume in droplets larger than $415 \mu \mathrm{m}$.

${ }^{5}$ Relative span $=\left(D_{v, 9}-D_{v, 1}\right) / D_{v, 5}$ where $D_{v, 5}$ and $D_{v, 1}$ are droplet diameter at 90,50 , and $10 \%$ cumulative spray volume. 
plot means were used in subsequent statistical analyses. Trees with no foliage after the second post-treatment growing season were considered dead. Differences between droplet size and spray volume were determined with a factorial analysis of variance to test for significance of interactions between site, droplet size, and spray volume. Fisher's protected least significant difference (L.S.D.) was used to identify treatment means differing at the $5 \%$ level.

\section{Results}

Honey mesquite mortality ranged from 58 to $80 \%$ among sprayed treatments and from 23 to $97 \%$ on individual sprayed plots. These treatment means are similar to those reported in other studies examining the effects of clopyralid on honey mesquite (Jacoby et al. 1990a, 1990b, 1991; Bovey and Whisenant 1991).

Site-by-treatment interactions were not significant for either the 1989 or 1990 experiments, indicating similar treatment response patterns occurred at both sites during each of the 2 treatment years. Therefore, data are pooled over sites (within an application year). No statistical comparisons of canopy reduction or mortality were made between the 2 application years, since the herbicide application rates differed $\left(0.58 \mathrm{~kg} \mathrm{ha}^{-1}\right.$ in 1989 versus $0.55 \mathrm{~kg} \mathrm{ha}^{-1}$ in 1990) and the 75 liters ha ${ }^{-1}$ treatments were not applied in 1990. There were no significant interactions between droplet size and spray volume in any of the analyses.

Each of these experimental applications required several hours to complete and weather parameters varied during that time. Some applications were made early in the morning when wind and temperature were low and the relative humidity high, while others were made during afternoon hours when temperature and wind were higher and relative humidity was low. Temperature, relative humidity, and wind speed ranged from 21 to $36^{\circ} \mathrm{C}, 17$ to $82 \%$, and 4 to $19 \mathrm{~km} \mathrm{hr}^{-1}$ at Andrews and from 19 to $31^{\circ} \mathrm{C}, 28$ to $81 \%$, and 2 to $13 \mathrm{~km} \mathrm{hr}^{-1}$ at Big Lake in 1989. At Campbellton, the temperature ranged from 25 to $36^{\circ} \mathrm{C}$, relative humdity 39 to $89 \%$, and wind speed 5 to $19 \mathrm{~km} \mathrm{hr}^{-1}$. In 1990 at Big Lake, the temperature, relative humidity and wind speed ranged from 20 to $27^{\circ} \mathrm{C}, 66$ to $92 \%$, and 2 to $14 \mathrm{~km} \mathrm{hr}^{-1}$, respectively.

Deposition of spray solutions on leaves, soda straws, and water sensitive cards was also determined during these experiments and is reported elsewhere (Bouse et al. 1992). No consistent trends were detected for the effect of droplet size on the deposit on plant leaves; but, smaller droplets tended to produce the highest deposits on soda straws. Droplet density (droplets $\mathrm{cm}^{-2}$ ) on water sensitive cards was greatest for small droplets and decreased with an increase in droplet size. Droplet density increased with increasing spray volume for most experiments, but not in direct proportion to the amount of spray volume increase (Bouse et al. 1992). Stepwise regression analysis was unable to identify the relative contributions of droplet size, spray solution onto mesquite leaves (Bouse et al. 1992).

\section{Spray Volume}

Following the 1989 applications, no significant differences in honey mesquite mortality or canopy reduction were detected between the 19 or 37 liters ha ${ }^{-1}$ volume treatments (Table 3). However, the 75 liters ha $^{-1}$ treatments produced significantly greater mortality and canopy reduction than either the 19 or 37 liters ha $^{-1}$ treatments (Table 3 ). Treatments with spray volumes of 37 liters ha ${ }^{-1}$ in 1990 had greater mortalities than the 19 liters ha ${ }^{-1}$ treatments, but canopy reductions were no different (Table 4).

Relative mortality, calculated by dividing measured mortality by the maximum mortality for each experimental site, was affected less by the different environmental conditions during and after applications. Since there were no significant treatment by site (or application year) interactions for relative mortality data, analyses
Table 3. Mortality and canopy reduction of honey mesquite in October 1990 following application of $0.58 \mathrm{~kg}$ ae clopyralid $\mathrm{ha}^{-1}$ at different combinations of droplet size and spray volume in June 1989 at Andrews and Big Lake, Texas. Droplet size evaluations are pooled over site and spray volume. Spray volume evaluations are pooled over site and droplet size.

\begin{tabular}{lccc}
\hline \hline & $\mathrm{N}^{1}$ & Mortality $^{2}$ & $\begin{array}{c}\text { Canopy } \\
\text { reduction }^{2}\end{array}$ \\
\hline $\begin{array}{c}\text { Droplet size } \\
(\mu \mathrm{m})\end{array}$ & & $(\%)$ & $(\%)$ \\
$0 \begin{array}{c}\text { (untreated) } \\
325\end{array}$ & 6 & $0 \mathrm{a}$ & $4 \mathrm{a}$ \\
475 & 18 & $76 \mathrm{~b}$ & $92 \mathrm{~b}$ \\
625 & 18 & $72 \mathrm{~b}$ & $92 \mathrm{~b}$ \\
Spray volume $\left.^{\text {(liters ha }}{ }^{-1}\right)$ & 18 & $71 \mathrm{~b}$ & $90 \mathrm{~b}$ \\
0 (untreated) & & & \\
19 & 6 & $0 \mathrm{a}$ & $4 \mathrm{a}$ \\
37 & 18 & $69 \mathrm{~b}$ & $89 \mathrm{~b}$ \\
75 & 18 & $71 \mathrm{~b}$ & $90 \mathrm{~b}$ \\
& 18 & $80 \mathrm{c}$ & $94 \mathrm{c}$ \\
\hline
\end{tabular}

' $N$ is the number of plots used to calculate the associated treatment mean. ${ }^{2}$ Means within a column and application parameter followed by the same letter are not significantly different according to Fisher's protected L.S.D. at the $5 \%$ significance level.

Table 4. Mortality and canopy reduction of honey mesquite in September 1991 following application of $0.55 \mathrm{~kg}$ ae clopyralid hat different combinations of droplet size and spray volume in July and June 1990 at Big Lake and Campbellton, Texas, respectively. Droplet size evaluations are pooled over site and spray volume. Spray volume evaluations are pooled over site and droplet size.

\begin{tabular}{|c|c|c|c|}
\hline & $\mathbf{N}^{1}$ & Mortality² & $\begin{array}{l}\text { Canopy } \\
\text { reduction }\end{array}$ \\
\hline $\begin{array}{l}\text { Droplet size } \\
\qquad(\mu \mathrm{m})\end{array}$ & & $(\%)$ & $(\%)$ \\
\hline 0 (untreated) & 6 & $2 \mathrm{a}$ & $20 a$ \\
\hline 325 & 12 & $75 c$ & $98 \mathrm{c}$ \\
\hline 475 & 12 & $71 \mathrm{c}$ & 97 bc \\
\hline 625 & 12 & $58 \mathrm{~b}$ & $94 \mathrm{~b}$ \\
\hline \multicolumn{4}{|c|}{$\begin{array}{l}\text { Spray volume } \\
\text { (liters ha } \text { ha }^{-1}\end{array}$} \\
\hline 0 (untreated) & 6 & $2 \mathrm{a}$ & $21 \mathrm{a}$ \\
\hline 19 & 18 & $63 \mathrm{~b}$ & $96 b$ \\
\hline 37 & 18 & $73 \mathrm{c}$ & $98 b$ \\
\hline
\end{tabular}

iN is the number of plots used to calculate the associated treatment mean. 2Means within a column and application parameter followed by the same letter are not significantly different according to Fisher's protected L.S.D. at the 5\% significance significa
level.

among all sites and application years were used. When averaged over droplet size, relative mortality increased with increasing spray volumes (Table 5). Applying clopyralid in 75 liters ha ${ }^{-1}$ total spray volume significantly increased relative mortality compared to the 19 liters $\mathrm{ha}^{-1}$ treatment, but neither differed from the intermediate spray volume treatment.

\section{Droplet Size}

Droplet size of the clopyralid spray solutions had no significant effect on honey mesquite mortality or canopy reduction following the 1989 applications (Table 3). Following the 1990 applications, mortality resulting from the largest $(625 \mu \mathrm{m})$ droplet size was significantly less than mortality from either the 325 or $475 \mu \mathrm{m}$ droplet size treatments (Table 4). Canopy reductions resulting from treatments containing the largest droplets were less than reductions from treatments receiving the smallest droplets, but were not different from canopy reductions resulting from the intermediate sized droplets (Table 4). 
Table 5. Relative mortality of honey miesquite following clopyralid applications at different droplet size and spray volume combinations in 1989 and 1990 at Andrews, Big Lake and Campbeliton, Texas. Droplet size evaluations and pooled over year, site, and spray volume. Spray volume evaluations are pooled over year, site, and droplet site.

\begin{tabular}{|c|c|c|}
\hline & $\mathbf{N}^{1}$ & $\begin{array}{c}\text { Relative } \\
\text { mortality }{ }^{2}\end{array}$ \\
\hline $\begin{array}{l}\text { Droplet size } \\
\qquad(\mu \mathrm{m})\end{array}$ & & $(\%)^{3}$ \\
\hline $\begin{array}{c}0 \text { (untreated) } \\
325 \\
475 \\
625\end{array}$ & $\begin{array}{l}12 \\
30 \\
30 \\
30\end{array}$ & $\begin{array}{l}1 \mathrm{a} \\
84 \mathrm{c} \\
80 \mathrm{bc} \\
74 \mathrm{~b}\end{array}$ \\
\hline \multicolumn{3}{|c|}{$\begin{array}{l}\text { Spray volume } \\
\text { (liters ha }^{-1} \text { ) }\end{array}$} \\
\hline $\begin{array}{c}0 \text { (untreated) } \\
19 \\
37 \\
75\end{array}$ & $\begin{array}{l}12 \\
36 \\
36 \\
18\end{array}$ & $\begin{array}{l}1 \mathrm{a} \\
74 \mathrm{~b} \\
81 \mathrm{bc} \\
87 \mathrm{c}\end{array}$ \\
\hline
\end{tabular}

IN is the number of plots used to calculate the associated treatment mean. 2Relative mortality is mortality on each plot as a percentage of the highest mortality on any plot treated at the same site and date.

any plot treated at the same site and date. significantly different according to Fisher's protected L.S.D. at the $5 \%$ significance level.

Relative mortality of honey mesquite treated with the smaller droplets $(325 \mu \mathrm{m})$ was significantly greater than relative mortality of honey mesquite treated with the largest droplets, but treatments receiving the intermediate droplets were not significantly different from either the 325 or $625 \mu \mathrm{m}$ treatments (Table 5).

\section{Discussion}

Two trends appeared consistently in these experiments, but were not always statistically significant. Honey mesquite mortality and canopy reduction were increased as spray volume increased. Mortality tended to be inversely related to droplet size of the spray mixture, i.e., honey mesquite mortality increased as droplet size decreased.

Droplet density has been suggested as being of major importance in the effectiveness of foliar-applied herbicides on honey mesquite (Behrens 1957). An average droplet spacing of 3,100 $\mu \mathrm{m}$ was suggested to provide the maximum effective droplet density of 11 droplets $\mathrm{cm}^{-2}$. In this study, reducing droplet size or increasing spray volume increased droplet density, and generally increased phytotoxicity.

Early research indicated that changing spray volume from 19 to 112 liters ha ${ }^{-1}$ did not affect honey mesquite mortality from ester formulations of 2,4,5-T (2,4,5-trichlorophenoxy acetic acid) (Fisher et al. 1956). Since that time, herbicide applications for honey mesquite control have routinely used spray volumes of 18 to 28 liters $\mathrm{ha}^{-1}$. Spray volumes from 5 to 37 liters ha $\mathrm{h}^{-1}$, containing 0.28 to $0.56 \mathrm{~kg}$ ae ha $\mathrm{ha}^{-1} 2,4,5-\mathrm{T}$ or $2,4,5-\mathrm{T}+$ picloram (4-amino-3,5,6trichloro-2-pyridinecarboxylic acid) aerially applied did not significantly affect honey mesquite mortality, but droplet sizes at various spray volumes were unknown (Fisher et al. 1974). Previous field studies examining the effect of spray volume on honey mesquite mortality were confounded by droplet size changes of unknown magnitude. Although spray volumes can be changed - within certain limits-without changing droplet size, it seldom occurs. Recent evidence indicates that the relationship between droplet size and spray pressure depends on nozzle orientation on the spray boom and can be opposite to the previous understanding, at least with fixed-wing applications. Previously, higher spray pressure was believed to always produce smaller droplets, so that an applicator would lower pressure in order to produce larger drops-and reduce drift potential. New evidence indicates that decreasing pres-

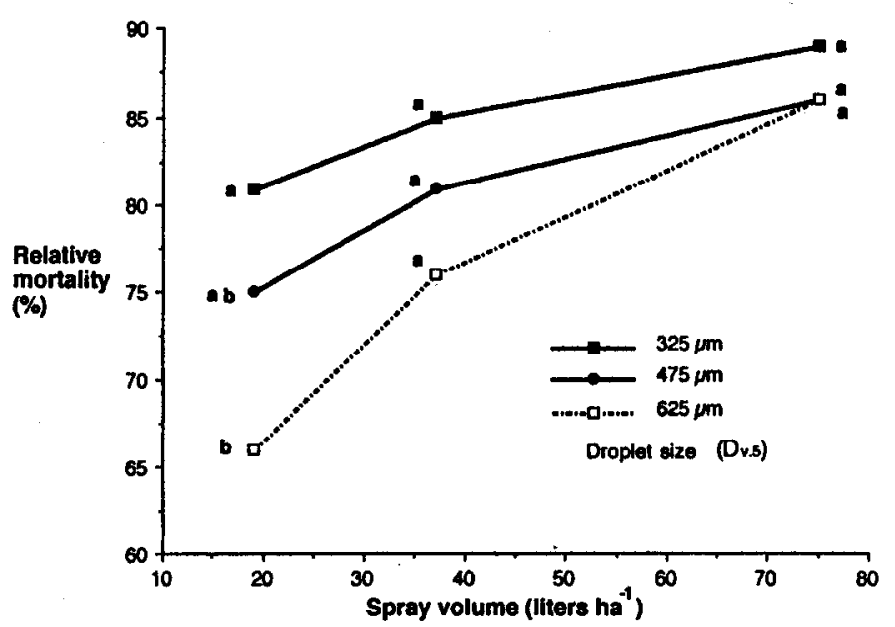

Fig. 1. Relative mortality of honey mesquite following clopyralid applications at 0.55 to $0.58 \mathrm{~kg} \mathrm{ha}^{-1}$ at different droplet size and spray volume combinations in 1989 at Andrews and Big Lake and in 1990 at Big Lake and Campbellton, Tex. Means within a spray volume followed by the same letter are not significantly different according to Fisher's protected L.S.D. at the $5 \%$ significance level. Relative mortality is calculated as mortality on each plot expressed as a percentage of the highest mortality on any plot treated at the same site and date. Each 19 and 37 liters ha point is the mean of 12 plots, which were treated at 4 sites in 1989 or 1990. Each 75 liters ha ${ }^{-1}$ point is the mean of 6 plots treated at 2 sites in 1989.

sure actually decreases droplet size for nozzles directed rearward at small angles to the direction of flight, due to the greater differential between spray mixture speed out of the nozzle and airstream speed (Bouse 1991). The greater speed differential between spray and airstream increases the windshear that reduces droplet size. As a result, much of our current understanding of drift reduction during aerial application may be wrong.

Phytotoxicity of foliar-applied herbicides is affected by distribution of the herbicide solution over the leaf surface and concentration of formulated herbicide in the spray solution. Within the range of spray volumes used in this study, the benefits of greater distribution of spray droplets apparently outweighed the potential problems associated with reduced herbicide concentration in the spray solution. In a greenhouse study, no differences in spray deposit on honey mesquite seedlings were found between droplet size spectrums of 160 or $330 \mu \mathrm{m} \mathrm{D} .5$ or spray solution applications of 47 or 187 liters $\mathrm{ha}^{-1}$ (Bovey et al. 1991). The relatively small range of droplet sizes in the Bovey et al. (1991) study may explain the lack of treatment differences.

Relative mortality was used to combine data from 4 sites and 2 application years. This facilitated the development of a graph which demonstrated the pattern of response over all the experiments (Fig. 1). This single figure illustrates the overall results of the entire study. At larger spray volumes, droplet size becomes less important. Greater volumes ( 75 liters $\mathrm{ha}^{-1}$ ) allow the use of $625 \mu \mathrm{m}$ spray droplets in situations where drift must be reduced. However, for most situations where treatment costs are critical, the $325 \mu \mathrm{m}$ droplets will allow the use of reduced ( 19 liters $\mathrm{ha}^{-1}$ ) spray volumes. However the potential for drift increases with decreasing droplet size. The percentage of spray volume in droplets smaller than approximately $200 \mu \mathrm{m}$ is considered to be an important factor in determining the degree of drift hazard.

\section{Literature Cited}

Behrens, R. 1957. Influence of various components on the effectiveness of 2,4,5-T sprays. Weeds 5:183-196. 
Bouse, L.F. 1991. Effect of nozzle type and operation on spray droplet size. Paper AA91-005. Joint meeting of Nat. Agr. Aviation Assoc./Amer Soc. Agr. Eng., 9 Dec. 1991, Las Vegas, Nev.

Bouse, L.F., I.W. Kirk, and L.E. Bode. 1990. Effect of spray mixture on droplet size. Trans. Amer. Soc. Agr. Eng. 33:783-788.

Bouse, L.F., S.G. Whisenant, and J.B. Carlton. 1992. Aerial spray deposition on mesquite. Trans. Amer. Soc. Agr. Eng. 35:51-59.

Bovey, R.W., and S.G. Whisenant. 1991. Control of honey mesquite with clopyralid, triclopyr, or clopyralid:triclopyr mixtures. J. Range Manage. 44:52-55.

Bovey, R.W., R.A. Stermer, and L.F. Bouse. 1991. Spray deposition of clopyralid on honey mesquite (Prosopis glandulosa). Weed Tech. 5:499-503.

Buhler, D.D., and O.C. Burnside. 1983. Effect of spray components on glyphosate toxicity to annual grasses. Weed Sci. 31:124-130.

Buhler, D.D., and O.C. Burnside. 1984. Effect of application factors on postemergence phytotoxicity of fluazifop-butyl, haloxyfop-methyl, and sethoxydim. Weed Sci. 32:574-583.

Buhler, D.D., and O.C. Burnside. 1987. Effect of application variables on glyphosate phytotoxicity. Weed Tech. 1:14-17.
Cranmer, J.R., and D.L. Linscott. 1991. Effects of droplet composition on glyphosate absorption and translocation in velvetleaf (Abutilon theophrasti). Weed Sci. 39:251-254.

Fisher, C.E., C.H. Meadors, and R. Behrens. 1956. Some factors that influence the effectiveness of (2,4,5-trichlorophenoxy)acetic acid in killing mesquite. Weed Sci. 4:139-147.

Fisher, C.E., C.H. Meadors, J.P. Walter, J.H. Brock, and H.T. Wiedemann. 1974. Influence of volume of herbicide carriers on control of honey mesquite. Tex. Agr. Exp. Sta. PR-3282.

Jacoby, P.W., C.H. Meadors, and R.J. Ansley. 1990a. Control of honey mesquite with herbicides: influence of plant height. J. Range Manage. 43:33-35.

Jacoby, P.W., R.J. Ansley, C.H. Meadors, and C.J. Cuomo. 1990b. Control on honey mesquite with herbicides: influence of stem number. $J$. Range Manage. 43:36-38.

Jacoby, P.W., R.J. Ansley, and C.H. Meadors. 1991. Late season control of honey mesquite with clopyralid. J. Range Manage. 44:56-58.

McKinlay, K.S., S.A. Brandt, P. Morse, and R. Ashford. 1972. Droplet size and phytotoxicity of herbicides. Weed Sci. 20:450-452.

McKinlay, K.S., R. Ashford, and R.J. Ford. 1974. Effects of droplet size, spray volume, and dosage on paraquat toxicity. Weed Sci. 22:31-34. 